\title{
Effect of Cadmium Chloride on the Histological Structure of Lung in Adult Male Mice with and without Parsley Oil
}

\author{
Maha Alsammak*(i) \\ Department of Anatomy, Histology and Embryology, College of Medicine, University of Mosul, Iraq
}

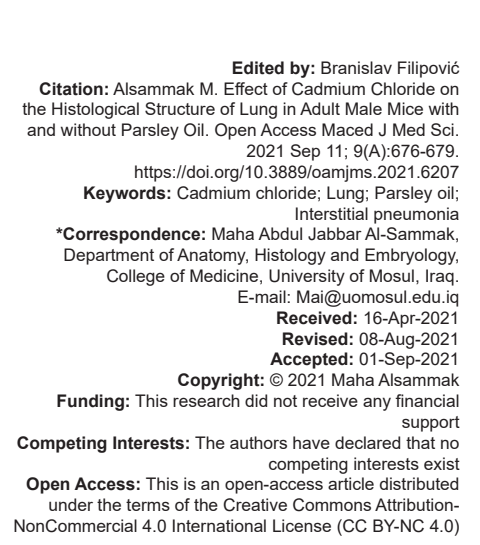

Introduction

Cadmium chloride is a heavy metal that causes environmental pollution it is widely present in the soil, food, air, and water in various concentration [1].

Cadmium toxicity cause many symptoms such as sore throat, tightness of the chest and abdominal pain. The lung is the main target organ for the toxic effect of cadmium [2]. Herbal remedies widely used such as parsley oil which has antioxidant, anti-inflammatory, and anticarcinogenic activities [3].

Cadmium chloride exerts its toxic effect by causing oxidative damage to cellular organelles by inducing the formation of reactive oxygen species [4].

Lead and cadmium are the two heavily toxic metals that mostly cause environmental pollution [5]. Contamination with cadmium chloride occurs also in the fish which take the heavy metal cadmium from the water and accumulated in the tissue to dangerous level. The risk in the human occurs by ingestion of fish containing cadmium [6].

Cadmium toxicity causes interference with essential metals which lead to induction of oxidative stress, inhibition of DNA repair, interference with apoptosis, and induction of active pulmonary inflammatory response [7].

\section{Animal Studies and Drug Treatment}

We obtained cadmium chloride from the biochemistry department in the college of medicine. Because of its high toxicity we used the safety measures which include mask and gloves. Parsley oil was bought from the local market. Animals were provided from the animal house in the college of veterinary medicine. They were kept under convenient circumstances. They adapted to the conditions 1 week before the experiment. They were caged in a temperature controlled environment. They were allowed to access food and water.

\section{Experimental Design}

40 adult male mice away $12-13$ weeks ranging 25-30 g in weight. 10 mice were kept in each plastic cage. They were divided into four groups.

Group A (control group) injected with normal saline intraperitonially single daily dose for 30 days. Group B injected intraperitonially with cadmium chloride in a dose $3.5 \mathrm{mg} / \mathrm{kg}$ body weight single daily dose for 
30 days. Group $\mathrm{C}$ injected intraperitonially by cadmium chloride in dose $3.5 \mathrm{mg} / \mathrm{kg}$ body weight and intragastric tube was put to receive parsley oil in a dose $0.5 \mathrm{ml} /$ $\mathrm{kg}$ body weight prior to the cadmium injection. The two drugs were given for 30 days. Group D receives $0.5 \mathrm{ml} / \mathrm{kg}$ body weight of parsley oil using gastric tube for 30 days. In the lower lateral part of the abdomen, the intraperitoneal injection was given [8]. At the end of the experiment, the animals were sacrificed and the lungs were collected from all groups, fixed in $10 \%$ neutral formalin dehydrated by alcohol and cleared by xylol and mounted in paraffin wax. Sections were taken from the block and stained with Harris hematoxylin and Eosin stain.

\section{Results}

Light microscoical observation of the lung tissue from the control group and from Group D showed normal histological structure including normal alveoli and normal inter alveolar septum. (Figures 1-4), respectively. In contrast Group $B$ receiving cadmium chloride showed many histological changes in the lung tissue including congestion, reduce alveolar space indicating interstitial pneumonia, massive inflammatory cell infiltration, thick interalveolar septum, and alveolar cellular damage (Figures 5 and 6). Group C treated with cadmium and parsley oil showed improvement in the histological structure of the lung so parsley oil preserved lung structure, no congestion, no infiltration, normal alveoli, and normal interalveolar septum (Figures 7 and 8).

\section{Discussion}

Cadmium is naturally distributed, but industrial development lead to dramatic increase in its concentration in the environment, the focus is to reduce its effect on the organs by herbal substances such as parsley oil used to decrease its toxicity. Lung tissue is one of the main targets of cadmium toxicity leading to lung damage, interstitial pneumonia, and inflammation of the lung [9].

Lung tissue from the control group showed normal appearance of the alveoli and normal interalveolar septum similar to those observed by other workers [10]. In this study, there is severe interstitial pneumonia with congestion and inflammatory cell infiltration; this is in agreement with the finding of Asl et al. [7], Farhan [11], and Jaafar [12]. Cadmium has been demonstrated to produce free radical leading to oxidative deterioration of lipid protein and DNA,

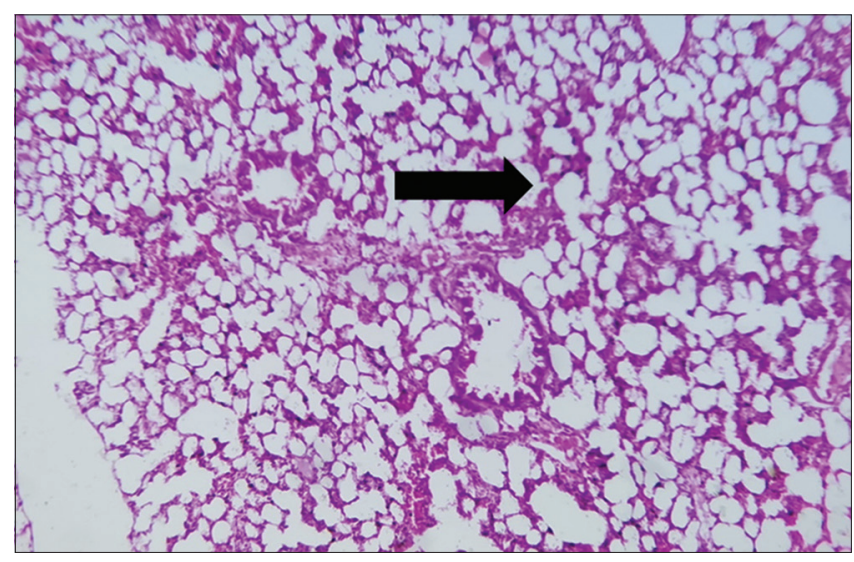

Figure 1: Tissue section from the lung of the control group (Group A) showing normal alveolus (black arrow) $(H$ and $E \times 100)$

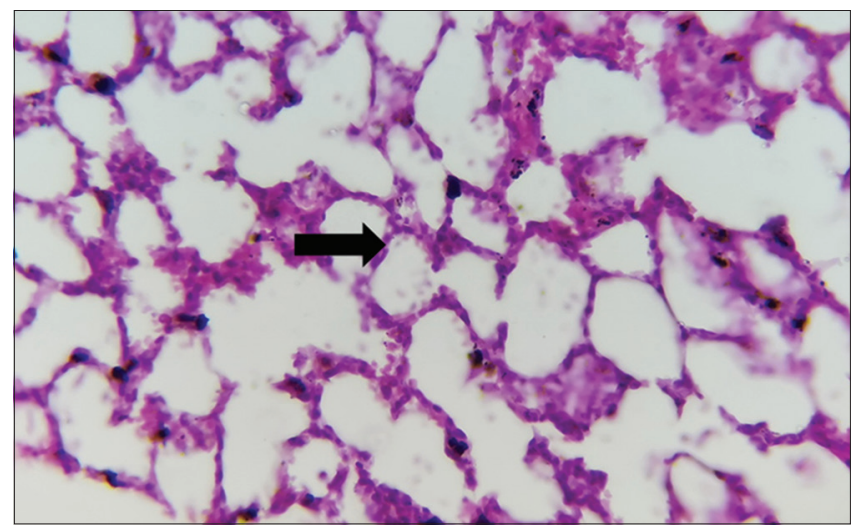

Figure 2: Tissue section from the lung of control group (Group A) showing normal interalveolar septum (black arrow) ( $H$ and $E \times 400)$

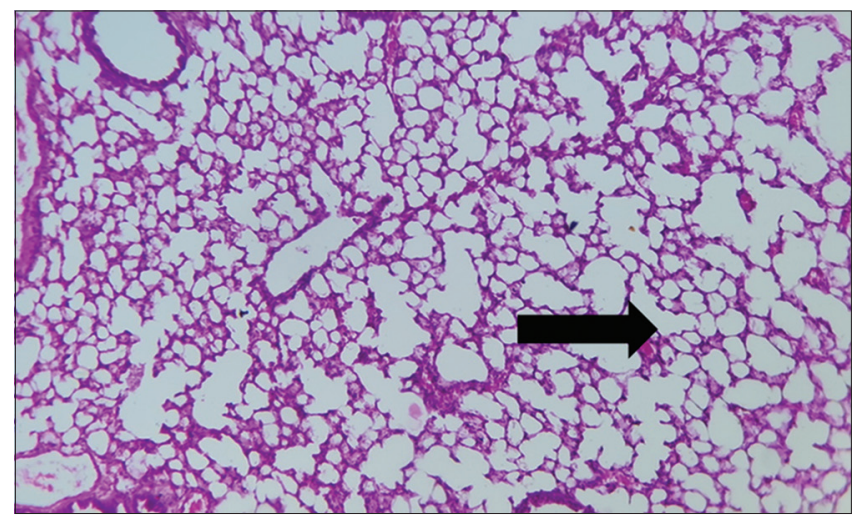

Figure 3: Tissue section from the lung of Group $D$ showing normal alveoli (black arrow) $(H$ and $E \times 100)$

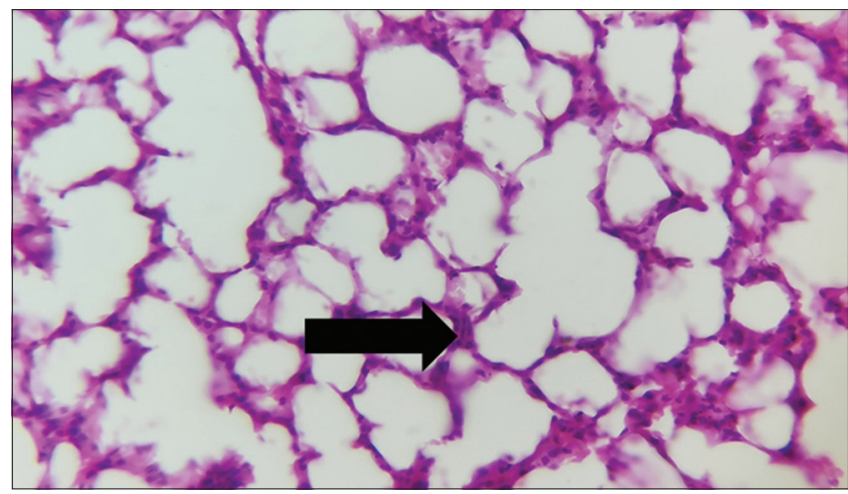

Figure 4: Tissue section from the lung of Group $D$ showing normal interalveolar Septum (black arrow) (H and $E \times 400)$ 


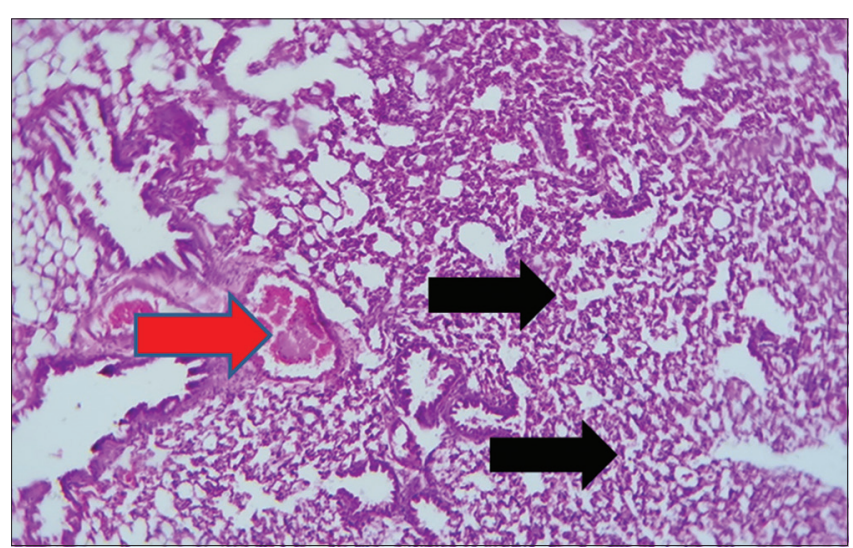

Figure 5: Tissue section from the lung of the treated group with cadmium (Group B) showing congestion (red arrow) reduce alveolar space (black arrows) ( $H$ and $E \times 100)$

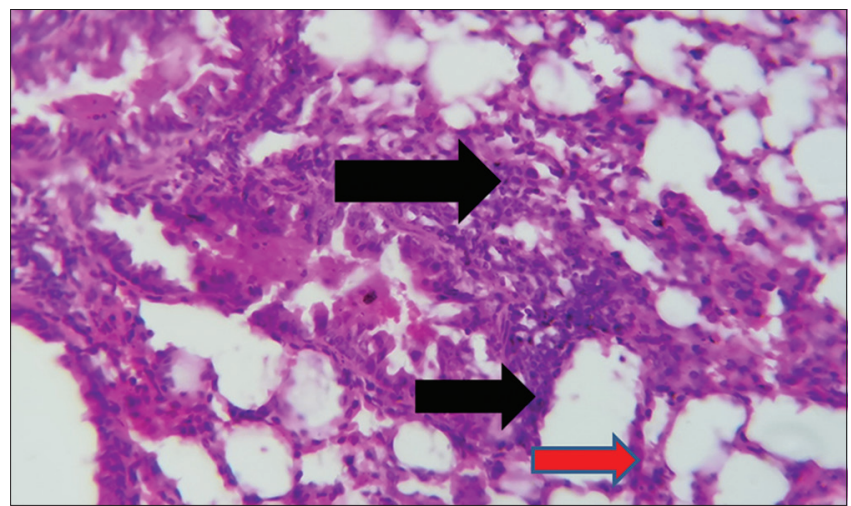

Figure 6: Tissue section from the lung of the treated group with cadmium (Group B) showed massive inflammatory cells infiltration (black arrows) thick interalveolar septum and cellular damage (red arrow) ( $H$ and $E \times 400)$

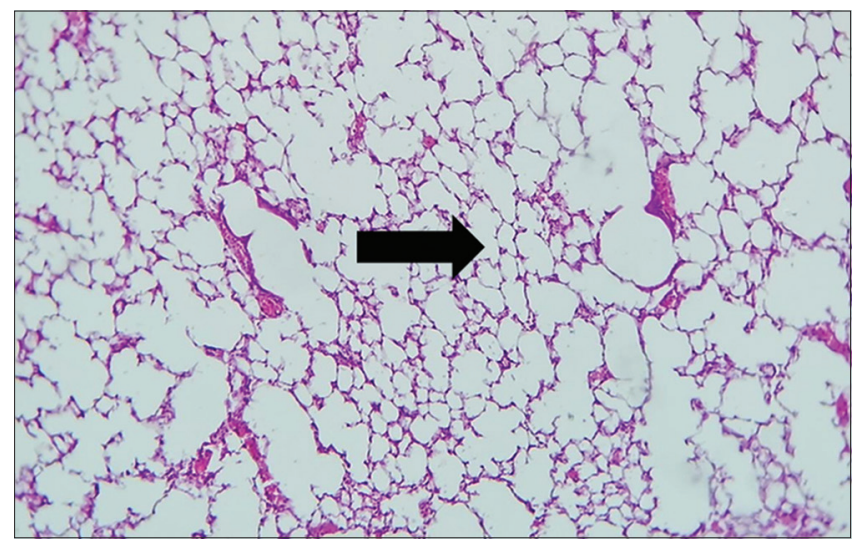

Figure 7: Tissue section from the lung of Group $C$ revaling nearly normal alveoli (black arrow) ( $H$ and $E \times 100)$

Cadmium induce apoptosis and/or necrosis of the cells through its formation of reactive oxygen species such as super oxide radicles, hydroxyl ion, and hydrogen peroxide [3], [4], [13].

In this study, damage to interalveolar septum involving pneumocyte type 2 which is responsible for the formation of surfactant and this substance is important

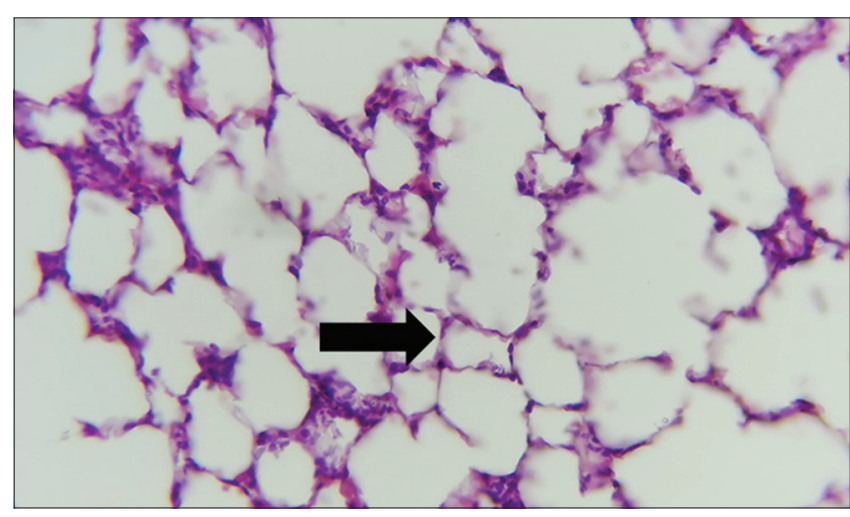

Figure 8: Tissue section from the lung of the Group $C$ showing reduce in the thickening of the interalveolar septum (black arrow) ( $H$ and $E \times 400)$

to prevent alveolar collapse and reduce alveolar tension so deficiency of this substance cause hypoxia and respiratory distress, this result is not mentioned by other workers. Oxidative damage is initiated by imbalance between oxidant and antioxidant resulting in mitochondrial damage and DNA damage which are the main manifestation of oxidative stress that occurs in cadmium toxicity [14], [15].

Concomtant use of antioxidants produce improvement in the histological structure of the organ, this finding is in agreement with the finding of other workers [16], [17], [18], [19], [20].

\section{Conclusion}

Cadmium chloride is a toxic heavy metal, lung is one of main organs affected by its toxicity, this study proves the toxicity of cadmium chloride in lung tissue which can be ameliorated using parsley oil.

\section{Acknowledgments}

We would like to express our sincere gratitude to staff members of animal house in college of veterinary medicine for their continuous support to complete this study.

\section{Ethical Approval}

The research was approved by Medical Research Ethics Committee, College of Medicine, University of Mosul 


\section{References}

1. Arab-Nozari M, Mohammadi E, Shokrzadeh M, Ahangar N, Amiri FT, Shaki F. Co-exposure to the non toxic levels of cadmium and fluoride induces hepatotoxicity in rats via triggering mitochondrial oxidative damage, apoptosis, and NF-KB pathways. Environ Sci Pollut Res Int. 2020;27(19):24048-58. https://doi.org/10.1007/s11356-020-08791-4

PMid:32304050

2. Oberdorster G. Pulmonary toxicity and carcinogenicity of cadmium. J Toxic. 1989;8(7):1251-61.

3. EL Shall EB, Badr GM. Effect of cadmium chloride on the liver of adult albino rats and the possible protective role of parsley oil Egypt. J Biomed Sci. 2012;38:12-36.

4. EL-Refaiy Al, Eissa FI. Histopathology and cytotoxicity as biomarkers in treated rats with cadmium and some therapeutic agents. Saudi J Biol Sci. 2013;20(3):265-80. https://doi. org/10.1016/j.sjbs.2013.02.004

PMid:23961244

5. AL-Khafaf AI, Ismail HK, AL-Saidya AM. Histopathological effects of experimental exposure to lead on nervous system in albino female rat. J Vet Sci. 2021;35(1):45-8. https://doi. org/10.33899/ijvs.2019.126248.1273

6. Ahmed AR. Evaluation of the heavy metal content in the muscle tissue of common carp (Cyprinus carpio L) reared in ground water in Basrah province, Iraq. Iraqi J Vet Sci. 2021;35(1):157-61. https://doi.org/10.33899/ijvs.2020.126491.1336

7. AsI SR, Khadjeh G, Jalali SM, Jamshidian J, ReZaie A. Investigating the protective effects of bromelain against inflammatory marker alterations induced by cadmium pulmonary intoxication in rats. Iran J Vet. 2020;16(2):75-88.

8. Taher MT, Al sammak MA, Al-Qazazz MM. Effect of doxorubicin on the histological structure of liver in male albino rats. Jordan Med J. 2013;47(3):220-6. https://doi.org/10.12816/0025817

9. AL-Kraie NI, Dalas IS, Razooqi QA. The toxic effect of cadmium chloride on lung function tissue and the effective role of pomegranate seed oil female rabbit Indian. J Med Toxicol. 2020;14(2):275-80. https://doi.org/10.37506/ijfmt.v14i2.2815

10. Danylchenko SI, Arctikov DS, Stavitskiy SO. Histological features of rats' normal lung tissue. Eur Int $\mathrm{J}$ Sci Technol. 2014;3(3):33-8.

11. Farhan AS. Effects of Tribulus terrestris fruits on renal and lung tissue in female mice administered with Cadmium. World J Vet. 2020;10:414-20. https://doi.org/10.36380/scil.2020.wvj51

12. Jaafar RS Bioremediation of lead and cadmium and the strive role of pediococcus pentosaceus probiotic. Iraqi $J$ Vet Sci. 2020;34(1):51-7. https://doi.org/10.33899/ ijvs.2019.125581.1092

13. AL-Derawi $\mathrm{KH}$. Effect of cadmium chloride on some endocrine glands (thyroid and adrenal) in male rats (Rattus norvegicus). Iraqi J Vet Sci. 2018;32(2):211-7. https://doi.org/10.33899/ ijvs.2019.153852

14. Abdeen A, Abou-Zaid OA, Abdel-Maksoud HA, Aboubakr M, Abdelkader A, Abdelnaby A, et al. Cadmium overload modulates piroxicam-regulated oxidative damage and apoptotic pathways. Environ Sci Pollut Res Int. 2019;26(24):25167-77. https://doi. org/10.1007/s11356-019-05783-x PMid:31256392

15. Fan R, Hu PC, Wang Y, Lin HY, Su K, Feng XS, et al. Betulinic acid protect mice from cadmium chloride-induced toxicity by inhibiting cadmium-induced apoptosis in kidney and liver. Toxicol Lett. 2018;299:56-66. https://doi.org/10.1016/j. toxlet.2018.09.003 PMid:30232032

16. Ismail HK. Histopathological alterations of male and female reproductive systems induced by alloxan in rats. Iraqi J Vet. 2020; 35(2):223-6. https://doi.org/10.33899/ijvs.2020.126626.1351

17. Sadiq SA, Jarjees MT. The histological and histochemical changes in the kidney of rabbit induced by diazinon. Iraqi J Vet. 2018;32(2):303-8. https://doi.org/10.33899/ijvs.2019.153868

18. Ahmad RM, AL-Hubaity AY, Alazow NS. The potential prevention role of Vitamin $C$ against structure changes in male rats liver induced by tramadol. Arab J Health Spec. 2019;28(4):647-66.

19. Ahmad RM, Al-HubataityA Y, Alazow NS. The role of Vitamin C on the structural changes of male Albino rats kidney induced by tramadol. Ann Coll Med Mosul. 2019;41(1):57-62. https://doi. org/10.33899/mmed.2019.161285

20. Abdullah RA, Taee FD, Thanoon IA. Effect of levofloxacin on some body tissues in mice. Iraqi J Vet Sci. 2020;35(1):109-11. https://doi.org/10.33899/ijvs.2020.126416.1316 